\title{
Hyperparathyroidism associated with chronic pancreatitis in a family
}

\author{
MARTIN C. CAREY AND OLIVER FITZGERALD \\ From the Department of Medicine and Therapeutics, University College, and \\ St Vincent's Hospital, Dublin
}

Hereditary hyperparathyroidism, occurring as an isolated endocrinopathy was first described by Goldman and Smyth in 1936. They described primary hyperparathyroidism in two siblings. Jackson and Boonstra (1967) collected 21 families with 107 hyperparathyroid members from the literature, including eight unrelated families of their own, all discovered in a single centre over a 10-year period. This condition tends to occur in younger patients who frequently have symptomless hypercalcaemia; the more likely parathyroid pathology is either chief-cell hyperplasia or multiple and re- current adenomas than the sporadic form. Other endocrine involvement in three different families suggested to these authors that hereditary hyperparathyroidism is most likely a part of the Mendelian dominant syndrome of hereditary endocrine adenomatosis which is characterized by pleomorphic expression.

Since 1957 when Cope, Culver, Mixter, and Nardi defined an association between hyperparathyroidism and pancreatitis, many cases of pancreatitis complicating prolonged hypercalcaemia have been reported. Its incidence in primary hyperparathy-

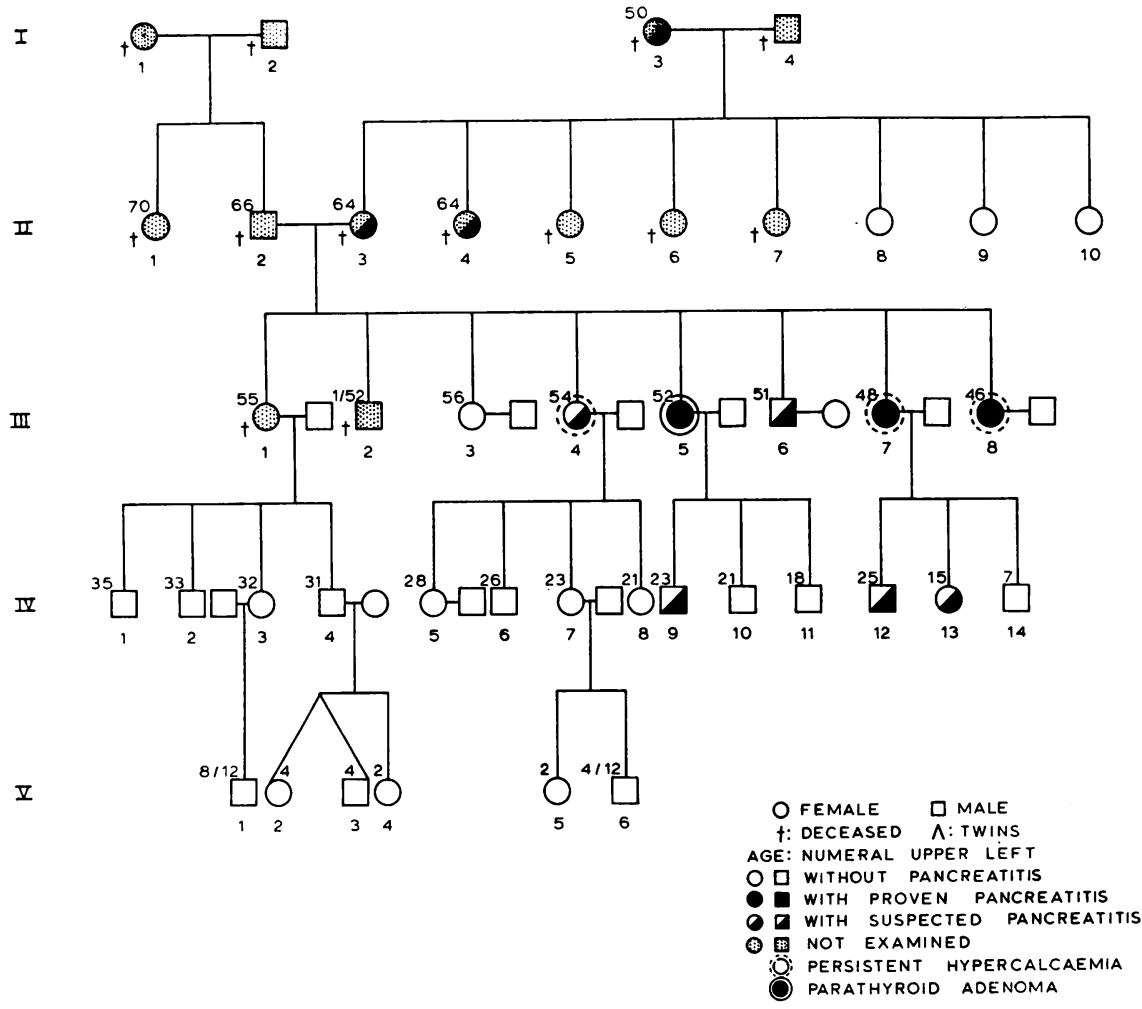

FIG. 1. Heredity of the family discussed in this paper in relation to both pancreatitis and parathyroid abnormalities. 
roidism varies directly with investigatory diligence and published rates range from $7 \%$ to $19 \%$. Chronic pancreatitis was present in a mother and her two sons in Jackson's (1957) original family of nine hyperparathyroid patients. In the same author's eighth family (Jackson and Boonstra, 1967) a 56year-old housewife was found to have a raised serum calcium level and a parathyroid adenoma weighing $0.45 \mathrm{~g}$ was removed. A review of the patient's mother's record revealed that she had died of acute pancreatitis at the age of 73 , had been normocalcaemic, but that an 'incidental' $0.5 \mathrm{~cm}$ oxyphil adenoma was found at necropsy.

The subject of the present report is a family we have studied since 1962 (Figure 1) in which there are three examples of chronic relapsing pancreatitis, all of whom are hypercalcaemic: neck explorations revealed a parathyroid adenoma in one (III-5) and normal parathyroids in the other (III-7). Two of these patients (III-7, III-8) had had surgery for pancreatitis several years before the calcium studies. Pancreatitis is suspected in eight other members, three of whom are dead, but only one (III-4) of those tested is hypercalcaemic.

\section{MATERIALS AND METHODS}

Kramer and Tisdall's (1921) method was used for the estimation of serum and urinary calciums; when high values were found the levels were checked using MacIntyre's (1961) flame photometric technique. Serum and urinary phosphates were measured after the method of King and Armstrong (1934). All hypercalcaemic patients were subjected to the cortisone suppression test of Dent (1956) which was continued for 10 days. The formula of Nordin and Frazer (1956) was used to calculate the urinary phosphate excretion index (PEI). In studying exocrine pancreatic function we used the evocative secretin-pancreozymin serum test of FitzGerald, FitzGerald, Fennelly, McMullin, and Boland (1963) and measured serum amylase and lipase according to the techniques of Myers, Free, and Rosinski (1944) and the modified Sigma-Tietz technique (Sigma Technical Bulletin, no. 800,1963$)$ respectively, the results being reported in terms of milligrams of reducing sugar and millilitres of $\mathrm{NaOH}$ respectively.

Urines were screened for abnormal aminoaciduria by two-dimensional paper chromatography and for porphobilinogen with the Watson-Schwartz test (1941). The glomerular filtration rate (GFR) was estimated by endogenous creatinine clearance. Routine clinical procedures were used for the other investigations.

\section{RESULTS}

The case summaries of the four siblings found to have a serum calcium level of $11.0 \mathrm{mg} \%$ or more are shown in Tables Ia and Ib. Cases III-7 and III-8 had chronic pancreatitis proven at laparotomy and in the case of III-5 the diagnosis rests on firm historical, clinical, and biochemical grounds. A three-day fat balance and stool nitrogen excretion and glucose tolerance tests were normal in all four. The cortisone supression tests failed to reduce the serum calcium levels significantly. Routine urinary screening tests for porphobilinogen excretion were negative but a significant lysine-cystine aminoaciduria was found in each case. Skeletal radiographs revealed nothing significant and pancreatic calcification was not detected.

During neck exploration a lower left parathyroid adenoma, $1.3 \mathrm{~cm} \times .75 \mathrm{~cm}$, was found in III-5 and removed. Clinical response was dramatic and serum and urinary calciums are now normal. During neck surgery on the proposita (III-7) only three parathyroids were identified and all except one fifth of one was removed. A recent serum calcium level was $8.6 \mathrm{mg} \%$. Histology of the excised glands was normal. Their other two sisters have refused parathyroid surgery.

The suspicion of pancreatitis in the five members who are dead (1-3, II-3, II-4) is tenable on the statements of their surviving siblings and offspring. Hospital studies for prolonged dyspepsia and pain in all three had not proven fruitful. Case III-6 is an alcoholic; his recurrent bouts of abdominal pain are typical of pancreatitis. Physical examination

TABLE Ia

CLINICAL AND LABORATORY FEATURES LEADING TO THE DIAGNOSIS OF PANCREATIC DISTURBANCE IN FOUR MEMBERS OF THE FAMILY

\begin{tabular}{|c|c|c|c|c|c|c|c|}
\hline $\begin{array}{l}\text { No. in } \\
\text { Pedigree }\end{array}$ & $\begin{array}{l}\text { Sex and } \\
\text { Age }\end{array}$ & $\begin{array}{l}\text { Initial } \\
\text { Serum Cal- } \\
\text { cium }(m g \%)\end{array}$ & $\begin{array}{l}\text { Maximum } \\
\text { Urinary Calcium } \\
(\mathrm{mg} / 24 \mathrm{hr})\end{array}$ & $\begin{array}{l}\text { PEI } \\
(\text { normal } \pm 0 \cdot 12)\end{array}$ & $\begin{array}{l}\text { GFR } \\
\text { (normal } 125 \mathrm{ml} / \mathrm{min})\end{array}$ & Aminoaciduria & Neck Exploration \\
\hline III-4 & F 54 & $11 \cdot 0$ & 463 & 0.250 & 115 & Lysine-cystine & Not done \\
\hline III-5 & F 52 & $12 \cdot 4$ & 362 & $0 \cdot 218$ & $\begin{array}{l}44 \cdot 7 \\
65 \cdot 4\end{array}$ & Lysine-cystine & $\begin{array}{l}\text { Single left lower } \\
\text { parathyroid adenoma }\end{array}$ \\
\hline \multirow[t]{2}{*}{ III-7 } & F 48 & $12 \cdot 0$ & 581 & $0 \cdot 215$ & 116.9 & Lysine-cystine & 3 normal parathyroids \\
\hline & & & & & & & $\begin{array}{l}2 \text { and four-fifths removed } \\
\text { Histology: normal }\end{array}$ \\
\hline III-8 & F 46 & $11 \cdot 4$ & 291 & $0 \cdot 108$ & $\begin{array}{l}77 \cdot 5 \\
71 \cdot 0\end{array}$ & Lysine-cystine & Not done \\
\hline
\end{tabular}


TABLE Ib

LABORATORY DATA RELATING TO THE DIAGNOSIS OF PARATHYROID OVERACTIVITY IN THE HEREDITY OF THE FAMILY

\begin{tabular}{|c|c|c|c|c|c|}
\hline $\begin{array}{l}\text { No. in } \\
\text { Pedigree }\end{array}$ & $\begin{array}{l}\text { Sex } \\
\text { and Age }\end{array}$ & $\begin{array}{l}\text { Relevant Symptoms } \\
\text { and History }\end{array}$ & Pancreatitis $^{1}$ & & $\begin{array}{l}\text { Comments and } \\
\text { Associated Conditions }\end{array}$ \\
\hline III-4 & F 54 & $\begin{array}{l}\text { Recurrent pancreatic pain }+ \text { flatulent } \\
\text { dyspepsia since age of } 6 \text {; worse during } \\
\text { pregnancies; headaches frequent }\end{array}$ & $\begin{array}{l}\text { Suspected } \\
1 \text { History }+ \text { tenderness } \\
\text { pancreas } \\
2 \text { Spot serum amylases: }\end{array}$ & $\begin{array}{l}\text { over } \\
2 \cdot 83 \\
3 \cdot 10\end{array}$ & $\begin{array}{l}\text { Previously jaundiced on } 2 \text { occasions } \\
\text { Recent cholecystogram and barium } \\
\text { meal (1965) normal }\end{array}$ \\
\hline III-5 & F 52 & $\begin{array}{l}\text { Typical pancreatic pain }+ \text { abdominal } \\
\text { tenderness for } 36 \text { yr, very severe during } \\
\text { menstruation and in pregnancies } \\
\text { Biparietal headaches + polyuria for } \\
12 \text { yr, dysuria and constipation for } 3 \mathrm{yr} \\
1944 \text {-euthyroid goitre noted } \\
1956 \text {-renal colic due to a solitary } \\
\text { calculus } \\
\text { 1957-67-chronic pyelonephritis }\end{array}$ & $\begin{array}{l}\text { Definite } \\
\text { 1 History + physical ex } \\
\text { 2 S-P test: amylase } \\
3 \cdot 17 \\
2 \cdot 67 \\
2 \cdot 84 \\
3 \cdot 00 \\
\\
\text { 3 Relief of pain after pa } \\
\text { roidectomy }\end{array}$ & $\begin{array}{l}\text { xamination } \\
\text { lipase } \\
1 \cdot 1 \\
0 \cdot 5 \\
0 \cdot 3 \\
0 \cdot 2 \\
\text { arathy- }\end{array}$ & $\begin{array}{l}\text { Small colloid goitre; renal } \\
\text { insufficiency (blood urea } 49 \mathrm{mg} \% \text {, } \\
\text { uric acid } 6.8 \mathrm{mg} \% \text {, viz. GFR) } \\
\text { Clinical and biochemical response to } \\
\text { parathyroidectomy } \\
\text { Serum calcium } 9.6 \mathrm{mg} \% \\
\text { Urinary calcium } 55 \mathrm{mg} / 24 \text { hours }\end{array}$ \\
\hline III-7 & F 48 & $\begin{array}{l}\text { Proposita: milk intolerance + pan- } \\
\text { creatic pain since childhood, worse } \\
\text { during menses and in pregnancies; } \\
10 \mathrm{lb} \text { weight loss } \\
\text { Steatorrhoea + depression on first } \\
\text { admission } \\
1961 \text {-Laparotomy-nil found } \\
\text { ?pancreas } \\
1962 \text {-S-P test abnormal—chronic } \\
\text { pancreatitis. Sphincterotomy + chole- } \\
\text { cystectomy } \\
\text { 1966-Constant back pain- } \\
\text { hypercalcaemia }\end{array}$ & $\begin{array}{l}\text { Definite } \\
\begin{array}{l}\text { 1 History + physical ex } \\
\text { 2 S-P test: } \begin{array}{c}\text { amylase } \\
3.0 \\
4 \cdot 28\end{array} \\
3.73 \\
3.0 \\
\text { 3 Positive laparotomy }\end{array}\end{array}$ & $\begin{array}{l}\text { amination } \\
\text { lipase } \\
0.8 \\
0.8 \\
1.4 \\
1.04\end{array}$ & $\begin{array}{l}\text { Small cyst at thyroid isthmus } \\
\text { removed } \\
\text { Normochromic anaemia }(\mathrm{Hb} 10.4 \mathrm{~g}) \\
\text { postoperative serum calcium } \\
12.5 \mathrm{mg} \% \text { but level now } \\
8.6 \mathrm{mg} \% \text {. }\end{array}$ \\
\hline III-8 & F 46 & $\begin{array}{l}\text { Periodic pancreatic pain accompanied } \\
\text { by syncope since childhood; milk } \\
\text { intolerance, constipation and lassitude } \\
\text { 1932-acute abdomen; treated } \\
\text { expectantly } \\
\text { 1964-laparotomy: partial gastrectomy } \\
\text { for a 'tumour proved to be an encap- } \\
\text { sulated area of fat necrosis saddling } \\
\text { lesser curvature } \\
\text { 1966-S-P test abnormal } \\
\text { Sphincterotomy and cholecystectomy } \\
\text { Subacute pancreatitis postoperatively } \\
\text { Hypercalcaemia }\end{array}$ & $\begin{array}{l}\text { Definite } \\
\begin{array}{l}\text { 1 History and physical e } \\
\text { 2 S-P test: } \quad \text { amylase } \\
\begin{array}{l}3 \cdot 0 \\
3 \cdot 78 \\
4.44 \\
4.67\end{array} \\
\\
\text { 3 Positive laparotomy }\end{array}\end{array}$ & $\begin{array}{l}\text { examination } \\
\text { lipase } \\
0.5 \\
0.6 \\
0.9 \\
0.7\end{array}$ & $\begin{array}{l}\text { Thyroid normal } \\
\text { anaemia mild (Hb } 11.0 \mathrm{~g}) \\
\text { Serum amylase: } 2.2 \mathrm{mg} \mathrm{R} . \mathrm{S} . / \mathrm{ml} \\
\text { after laparotomy. }\end{array}$ \\
\hline
\end{tabular}

Amylase mg R.S/ml:2.9 lipase STU/ml: 1.3 normal max.

showed widespread upper abdominal tenderness. A spot serum calcium, phosphate and amylase were normal.

In generation IV only those with complaints have been studied: calcium and amylase studies on IV-9, IV-12, and IV-13 were normal but in these the early onset of indigestion and abdominal pain and tenderness may be indicative of pancreatitis as gastroduodenal radiology was otherwise normal.

It is of interest that III-3 was found to have a toxic goitre in 1959 and was treated with ${ }^{131}$ I. During a cholecystectomy for cholelithiasis in 1963, the pancreas was palpably normal. A recent serum calcium level was $10.3 \mathrm{mg} \%$. The Table indicates that III-5 and III-7 also had small goitres.

\section{DISCUSSION}

In this family there is a ready explanation for chronic pancreatitis in those members with hypercal- caemia. However, in those who survive with suspected pancreatitis the explanation is not easily apparent. If III-6 proves to have definite pancreatitis, his long history of alcoholism is the most likely precipitating cause as the serum calcium level is normal. One interesting finding in all those examined with pancreatitis was lysine-cystine aminoaciduria, a feature reported in $50 \%$ of the individuals in families with hereditary pancreatitis originally described by Comfort and Steinberg (1952) and recently summarized by Gross, Ulrich, and Maher (1962) which feature has hitherto been confined to six families under observation at the Mayo Clinic. We have not found any evidence in the present series of the severe pancreatic endocrine and exocrine insufficiency which is mentioned as typical of the latter condition, nor have we found the heavy pancreatic calcification which, in the adult in the absence of alcoholism, is nearly a sine qua non for 
the diagnosis of hereditary pancreatitis. Two possible explanations for the aminoaciduria in the present kindred is the independent coexistence of the incompletely recessive form of lysine-cystinuria (Harris, Mittwock, Robson, and Warren, 1955) or it may be due to hypercalcaemic renal glomerulotubular damage as evidenced by an impaired GFR in two patients (Table Ib). The absence of radiological bone change in the presence of hyperparathyroidism may be attributable to increased calcium intake and/or absorption which is able to balance the urinary calcium loss. We found that the $\mathrm{Ca}^{++}$ content of the water from the district this family lived in, a limestone area, was $1.48 \mathrm{~m}$-equiv/litre which is 20 times the calcium content of London drinking water.

In agreement with what Jackson and Boonstra (1967) have drawn attention to we have found that three individuals in this family had goitres; one patient developed hyperthyroidism. Perhaps in this family we are also dealing with hereditary endocrine adenomatosis, although evidence of other glandular involvement is wanting.

\section{SUMMARY}

A family with hereditary hyperparathyroidism and relapsing chronic pancreatitis is described. Parathyroid pathology was found in only one member. In another, subtotal resection of the parathyroids was carried out, causing a fall in serum calcium to a hypoparathyroid level. Two other hypercalcaemic members with pancreatitis have declined further study or surgery.

Drs Ailish Forristal (Kilkenny), Thomas P. Walsh (New Ross), and Michael G. O'Brien (Inistioge) assisted us considerably in studying this family. Professor Patrick
FitzGerald carried out both neck explorations and $\mathrm{Dr}$ Robert Towers reviewed all the histological specimens. This study was carried out during the tenure of a fulltime research fellowship of the Medical Research Council of Ireland awarded to one of us (M.C.C.).

Reprint requests to be sent to O.F.

\section{REFERENCES}

Comfort, M. W., and Steinberg, A. G. (1952). Pedigree of a family with hereditary chronic relapsing pancreatitis. Gastroenterology, 21, 54-63.

Cope, O., Culver, P. J., Mixter, C. G., Jr, and Nardi, G. L. (1957). Pancreatitis, a diagnostic clue to hyperparathyroidism. Ann. Surg., 145, 857-863.

Dent, C. E. (1956). Cortisone test for hyperparathyroidism. Brit. med. J., $1,230$.

FitzGerald, O., FitzGerald, P., Fennelly, J., McMullin, J. P., and Boland, S. J. (1963). A clinical study of chronic pancreatitis. Gut, 4, 193-216.

Goldman, L., and Smyth, F. S. (1936). Hyperparathyroidism in siblings, Ann, Surg., 104, 971-981.

Gross, J. B., Ulrich, J. A., and Maher, F. T. (1962). Further observations on the hereditary form of pancreatitis. In Ciba Foundation Symposium on the Exocrine Pancreas, pp. 278-309. Edited by A. V. S. de Reuck and M. P. Cameron. Churchill, London.

Harris, H., Mittwoch, U., Robson, E. B., and Warren, F. L. (1955). Phenotypes and genotypes in Cystinuria. Ann. hum. Genet., 20, 57-91.

Jackson, C. E. (1958). Hereditary hyperparathyroidism associated with recurrent pancreatitis. Ann. intern. Med., 49, 829-836.

_- and Boonstra, C. E. (1967). The relationship of hereditary hyperparathyroidism to endocrine adenomatosis. Amer. J. Med., 43, 727-734.

King, E. J. and Armstrong, A. R. (1934). A convenient method for determining serum and bile phosphatase activity. Canad. med. Ass. J., 381, 376-381.

Kramer, B., and Tisdall, F. F. (1921). A simple technique for the determination of calcium and magnesium in small amounts of serum. J. biol. Chem., 47, 475-481.

MacIntyre, I. (1961). Estimation of calcium in biological fluids and tissues by flame photometry. Advanc. clin. Chem., 4, 19-26.

Myers, V. C., Free, A. H., and Rosinski, E. E. (1944). Studies on animal diastases. VI. The determination of diastase (amylase) in blood. J. biol. Chem., 154, 39-48.

Nordin, B. E. C., and Frazer, R. (1956). The indirect assessment of parathyroid function. In Ciba Foundation Symposium on Bone Structure and Metabolism., pp. 222-238. Churchill, London.

Sigma Technical Bulletin (1963). Edited by G. E. W. Wolstenholme and C. M. O'Connor. No. 800. The Titrimetric Determination of Serum Lipase.

Watson, C. J., and Schwartz, S. (1941). A simple test for urinary porphobilinogen. Proc. Soc. exp. Biol. (N.Y.), 47, 393-394. 